\title{
Analiza različitih aspekata partnerskih odnosa kod polaznika zaručničkih tečajeva i važnost vjere u njihovu životu
}

\author{
Antun Volenik*, Slavica Blažeka Kokorić**, Maja Laklija***
}

\begin{abstract}
Sažetak
U radu su prikazani rezultati istraživanja provedenoga na uzorku od 245 osoba (122 para) koji polaze zaručnički tečaj kao sastavni dio bliže pripreme za sklapanje sakramentalnoga braka u okviru Katoličke crkve. Cilj je istraživanja bio ispitati obilježja partnerskih odnosa zaručnika koji se nalaze u fazi bliže pripreme za brak koji u sebi uključuje sakramentalnu dimenziju. Dodatno, istraživanjem se željelo provjeriti postoje li razlike u obilježjima partnerskih odnosa ovisno o procjeni važnosti vjere u osobnom životu sudionika istraživanja. Dobiveni rezultati pokazali su da je kod $71 \%$ sudionika istraživanja prisutan zajednički život zaručnika prije braka, $11 \%$ njih ulazi u brak s trudnoćom, a još $8,3 \%$ s već rođenim zajedničkim djetetom. Kod zaručnika koji procjenjuju važnost vjere u osobnom životu višim procjenama, bitno je rjeđe prisutna kohabitacija.
\end{abstract}

Ključne riječi: brak; sakrament ženidbe; priprema za brak; partnerski odnosi

\section{Uvod}

Prema podatcima iz posljednjih dvaju popisa stanovništva 2001. i 2011. godine, gotovo 90\% stanovništva Republike Hrvatske izjasnilo se pripadnicima Katoličke crkve (87,9\% 2001. godine i 86,2\% 2011. godine) (Državni zavod za statistiku, s. a.b). Istovremeno, statistički podatci pokazuju da je u posljednjem desetljeću u Hrvatskoj došlo do bitnoga opadanja broja brakova sklopljenih u

* Doc. dr. sc. Antun Volenik, Fakultet filozofije i religijskih znanosti Sveučilišta u Zagrebu. Adresa: Jordanovac 110, 10000 Zagreb, Hrvatska. ORCID iD: https://orcid.org/0000-0002-10173218. E-adresa: voleniksj@gmail.com

** Prof. dr. sc. Slavica Blažeka Kokorić, Studijski centar socijalnog rada, Pravni fakultet, Sveučilište u Zagrebu. Adresa: Nazorova 51, 10000 Zagreb, Hrvatska. ORCID iD: https://orcid.org/00000002-3846-8384. E-adresa: sblazeka@pravo.hr

*** Izv. prof. dr. sc. Maja Laklija, Studijski centar socijalnog rada, Pravni fakultet, Sveučilište u Zagrebu. Adresa: Nazorova 51, 10000 Zagreb, Hrvatska. ORCID iD: https://orcid.org/0000-00022580-4983. E-adresa: maja.laklija@pravo.hr 
vjerskom obliku. Godine 2009. samo je 36,5\% brakova bilo sklopljeno u građanskom obliku. ${ }^{1}$ Recentni podatci Ministarstva uprave pokazuju da je 2019. godine po prvi put broj brakova sklopljenih u građanskom obliku $(\mathrm{N}=9.996)$ nadmašio broj vjerski sklopljenih brakova $(\mathrm{N}=9.946)$ (Ministarstvo uprave, 2020). Navedeni pokazatelji svakako ukazuju na određene društvene procese i aktualne promjene u pristupu novih generacija mladih poimanju smisla i poželjnoga načina sklapanja braka.

U suvremenom društvu dolazi do pomaka u etapama sazrijevanja mlade generacije, pri čemu suvremena mladež nastoji produljiti razdoblje od stjecanja socio-ekonomske neovisnosti do zasnivanja vlastite obitelji te trajnije životne odluke o zasnivanju obitelji i ulasku u brak često odgađa za kasniju dob (Ilišin, 2002, 31). Mladi u današnje vrijeme najveći dio svojega mladenaštva, a ponekad i rane odrasle dobi, provode bez ulaska u brak, no istovremeno ne i bez partnerskih ili ljubavnih veza, koje se manifestiraju u različitim nevjenčanim formama, bilo da je riječ o povremenim izlascima s partnerom, održavanju redovitih kontakata bez zajedničkoga života s partnerom ili o zajedničkom životu s partnerom u izvanbračnoj zajednici, tzv. kohabitaciji (Blažeka Kokorić, 2005, 10). Kada su u pitanju partnerske veze, većina mladih ljudi u svojim aktualnim ili mogućim potencijalnim vezama, u tzv. "hodanju s nekim", ne vidi smisao pripreme za budući bračni život, nego takve veze i bliske odnose doživljavaju kao same sebi svrhom (Aračić, 2000, 24-33).

U razvijenim zapadnim zemljama odavno je prepoznat trend porasta broja parova koji se odlučuju na zajednički život (kohabitaciju) prije stupanja u brak. Kohabitacija se obično definira kao oblik zajedničkoga intimnoga života heteroseksualnih parova bez građanske ili crkvene registracije (Seltzer prema ČudinaObradović i Obradović, 2006, 57). U odnosu na bračni život kohabitacija obično uključuje manji stupanj odanosti i obvezivanja među partnerima, labaviju vezu te veću individualnu autonomiju u partnerskom odnosu, koja je često popraćena odvojenim financijama te većom uključenošću oba partnera u obavljanje kućanskih poslova (Čudina-Obradović i Obradović, 2006, 59; Stafford et al., 2004, 233).

Kohabitacija se je kao društvena pojava pojavila 70-tih godina 20. stoljeća, najprije u skandinavskim zemljama a zatim u Sjevernoj Americi, odakle se je proširila i na druge europske zemlje (Selzer prema Čudina-Obradović i Obradović, 2006, 57). U posljednjih 50-tak godina došlo je do nagloga porasta broja parova koji žive u kohabitaciji. Primjerice, procjenjuje se da je u SAD-u u periodu od

1 U Hrvatskoj se brak može sklopiti u građanskom obliku (pred matičarom) ili u vjerskom obliku s učincima građanskoga braka (pred službenikom vjerske zajednice koja s Republikom Hrvatskom ima uređene pravne odnose). No to nije bio slučaj u ne tako davnoj prošlosti. Vrijedi podsjetiti da je od 1946. do 1999. u Hrvatskoj bio obvezan građanski brak koji se je zaključivao pred nadležnim državnim tijelom (Hlača, 2006). Tek je 1998. godine Obiteljskim zakonom u čl. 6 omogućeno sklapanje braka u građanskom ili vjerskom obliku (Hlača, 2006, 1067). Sklapanjem ugovora između Svete Stolice i Republike Hrvatske propisano je da kanonska ženidba od trenutka sklapanja ima građanske učinke prema odredbama zakonodavstva Republike Hrvatske ako ugovorne strane nemaju civilne zapreke i ako su ispunjeni propisi predviđeni odredbama zakonodavstva Republike Hrvatske (Hlača, 2006, 1066). 
1960. do 2009. godine broj parova koji žive zajedno u nevjenčanim vezama porastao za više od 10 puta (s 0,6 milijuna na oko 7,5 milijuna) (Strong et al., 2011, 310).

Slični trend doduše nešto blažega porasta stopa zajedničkoga života nevjenčanih parova prisutan je i u Hrvatskoj. Očito je da je brak danas izgubio na svojoj ekskluzivnosti i institucionalnosti kao jedinoj legitimnoj formi seksualnoga života i stvaranja obitelji (Čalić, 1995). Nakon upoznavanja, prije zaruka ili samoga vjenčanja, kod mnogih parova prethodi jedna duža ili kraća faza zajedničkoga života. Jednako tako određen broj parova odlučuje se na izvanbračnu zajednicu kao trajni, alternativni oblik zajedničkoga života bez sklapanja tradicionalne institucije braka. Takvi parovi često ne žele vjenčanje upravo zato što smatraju svoju vezu brakom i bez vjenčanoga lista (Čalić, 1995). Tomu u prilog govore podatci o broju sklopljenih brakova u Hrvatskoj, koji osjetno pada (od 1950. do 2019. godine prosječan broj sklopljenih brakova pao je s 38.094 na 19.942 brakova godišnje), te o broju djece rođene izvan braka, koji je u porastu (od 1950. do 2018. godine porastao je s 8,8\% na 20,7\% (Mrđen, 1997, 65; Državni zavod za statistiku, 2019, 11). Očito je da sve veći broj parova odvaja trudnoću i odgoj djece od tradicionalne institucije braka te odabire kohabitaciju kao dugoročniju alternativu bračnomu životu. Ipak, treba reći da, za razliku od većine drugih europskih zemalja, većina nevjenčanih parova u Hrvatskoj ipak nakon trudnoće žene ulazi u brak te ne ostaje živjeti izvanbračno (Alinčić et al., 2001, 124). Tomu u prilog govore podatci iz posljednjega popisa stanovništva iz 2011., koji su pokazali da se 52,83\% stanovnika starijih od 15 godina nalazi u braku, a samo 2,69\% stanovnika iznad 15-te godine života živi u izvanbračnoj zajednici (Državni zavod za statistiku, s. a.a). Navedeno činjenično stanje govori da je u Hrvatskoj situacija nešto drugačija nego u razvijenim zapadnim zemljama, odnosno da se kod nas parovi češce odlučuju za kohabitaciju kao prijelaznu fazu u svojem partnerskom odnosu prije konačne odluke o ulasku u brak ili o raskidu odnosa, a manje je onih koji ju prihvaćaju kao svoje trajno životno opredjeljenje.

Općenito gledajući, prikazani trendovi o pluralizmu životnih stilova i formi partnerskih veza kod današnje generacije mladih posredno upućuju na zaključak da mladi ljudi danas ozbiljno preispituju značenje i pravi smisao institucije braka. Ipak, neosporno je da se braku i danas pridaje velika pažnja, bilo u pozitivnom, bilo u negativnom kontekstu. Postojeće teorije temeljene na izučavanju socijalnih utjecaja i kulturoloških stereotipa pojašnjavaju da u tom području važnu ulogu imaju očekivanja koja pojedinac ima od braka, a koja su najčešce povezana s prethodnim iskustvima iz primarne obitelji te s prihvaćanjem određenih društvenih vrijednosti, stavova prema braku i određenih idealiziranih uvjerenja o partnerskoj ljubavi (Blažeka Kokorić, 2005, 118; Axinn i Thornton, 1992, 360).

Unatoč prisutnomu pluralizmu životnih stilova, potrebno je naglasiti da je brak i dalje najčešći oblik zajedničkoga života partnera kojim osobe koje ulaze u brak potvrđuju između sebe i pred zajednicom postojanje specifične bliske veze između njih (Blažeka Kokorić, 2005, 4). Komparativna studija vrijednosti u Europi (European Values Study) pokazala je da u Hrvatskoj $80 \%$ i više ispitanika 
smatra da brak nije zastarjela institucija (Baloban et al., 2019, 70). ${ }^{2}$ Institucija braka u Hrvatskoj je zaštićena Ustavom, koji člankom 62 brak definira kao životnu zajednicu žene i muškarca (Ustavni sud Republike Hrvatske, 2014).

U suvremenoj sociološkoj literaturi često se naglašava da u modernom društvu dolazi do jačanja individualizacije i pluralizma životnih oblika i vrijednosti, do porasta mogućnosti izbora, ali i kompleksnosti polja odlučivanja te do sve naglašenije potrebe za samoodređenjem, što vodi k jačanju konfliktnoga potencijala u obitelji popraćenoga većom nestabilnošću braka (Haralambos i Holborn, 2002, 563-584; Kregar et al., 2014, 305-307). U takvom društvenom okruženju pitanje izbora bračnoga partnera, donošenje odluke o ulasku u brak, definiranje poželjnoga modela braka te propitivanje smisla institucije braka postaje sve kompleksnije i zahtjevnije.

Ono po čemu se može prepoznati "dobar brak" od "lošega braka" svakako su njegovi plodovi jer »kad bračnom paru uspijeva živjeti dobar brak, onda su ne samo oni sretni nego i njihova obitelj, rodbina pa i društvo. Sretno bračno stanje je najbitniji uvjet za sretnu obitelj i društvo « (Čalić, 1995, 5). ${ }^{3}$

Danas je postalo uobičajeno da se okvir za vrjednovanje institucije braka svede na prizmu procjene trenutačnoga zadovoljstva i sreće partnera u partnerskom odnosu. Budući da se na taj način cjelokupna važnost institucije braka svodi na procjenu zadovoljstva osobnim odnosom između supružnika, brak postaje sve krhkiji jer svaki poremećaj na toj razini ugrožava sam opstanak braka i dovodi do sve veće nestabilnosti te društvene institucije (Koračević, 1999, 274-275). U kontekstu svjetovnoga poimanja braka kao korisne društvene institucije, brak u modernom društvu više nije nužnost ni očita vrijednost, nego on postaje predmet subjektivne odluke svakoga od supružnika, koji ga mogu po želji prekinuti kada procijene da se postojeći bračni odnos više ne uklapa u njihovu viziju poželjnoga bračnoga života (Čalić, 1995).

\section{Kršćanski brak}

Takvoj viziji i profanomu pristupu poimanju nekršćanskoga braka u pluralističkom društvu stubokom se protivi sakramentalna priroda kršćanskoga braka. U pozadini termina kršćanski brak njegova je sakramentalna posebnost na teološkoj razini. Tradicija se, osobito na Zapadu, već stoljećima poziva na sv. Augustina i njegov nauk o tri ženidbena dobra zbog kojih su brak i obitelj u kršćanstvu vrijednosne ustanove: vjernost i jedinstvo (fides), djeca (proles) i nerazriješivost

2 Treba naglasiti da je postotak ispitanika koji su se složili s navedenom tvrdnjom da »brak nije zastarjela institucija « 1999. godine iznosio $92 \%, 2008$. godine $82 \%$, a 2018. godine $80 \%$ (Baloban et al., 2019, 73), što govori u prilog postupnoga smanjivanja udjela ispitanika koji smatraju da brak nije zastarjela institucija.

3 Valja spomenuti i rezultate komparativnoga istraživanja vrijednosti u Europi (EVS) provedenoga 2018. godine u Hrvatskoj, koje je pokazalo da ispitanici kao dva najvažnija uvjeta za uspjeh braka ili partnerstva u najvišem postotku navode vjernost (97\%) i djecu (93\%) (Baloban et al., 2019, 70). 
(sacramentum). Tu se moramo kratko osvrnuti i na biblijsku viziju braka, odnosno njezinu judeo-kršćansku pozadinu sažetu u dva biblijska izvještaja o stvaranju. U tom kontekstu posebno je važno istaknuti judeo-kršćansku antropologiju, koja se temelji na personalističkim tekstovima stvaranja čovjeka, pri čemu se osobito ističe tzv. drugi izvještaj o stvaranju (Post 2,4-25), koji nadopunjuje prvi izvještaj stvaranja po Božjoj slici (Post 1,27). Od mnogih starozavjetnih biblijskih tema povezanih s brakom spomenimo i onu najvažniju o braku kao savezu koji se može prometnuti u bludništvo (Hoš 1-3). Sržno se može reći da starozavjetna vizija braka, unatoč ključnim personalističkim tekstovima (Post 23-25, Pjesma nad pjesmama), teži vrijednostima patrijarhalnoga društva u kojima u vrjednovanju braka i obitelji prevladavaju brojnost djece, važna uloga plemena i naroda, a sve dodatno podcrtano mesijanskom idejom. U kršćanskom, sakramentalnom poimanju braka najvažnije je naglasiti novozavjetni odnos prema braku koji puno jasnije ocrtava važnost osobe, osobito kroz Isusov odnos prema ženama. Važno je napomenuti da se slikom zaruka i završava kršćanska Biblija, a nadopunjuje se idejom beženstva i djevičanstva »radi kraljevstva nebeskoga«. Ne može se razumjeti kršćansko poimanje braka bez toga nadopunjavanja, koji se bazira na eshatološkim temeljima, a koji oslikava i smještaj sakramenata braka i svećeničkoga reda u skup sakramenata služenja i zajedništva, kako to navodi Katekizam Katoličke crkve (CCE 1534-1535).

Današnja vizija braka u pastoralnoj djelatnosti Crkve duboko je povezana s vizijama i željama Drugoga vatikanskoga koncila te naputcima i nadahnućima kasnijega pisanja Učiteljstva, osobito nekim enciklikama i pobudnicama Pavla VI. (Humanae vitae), Ivana Pavla II. (Familiaris consortio) i pape Franje (Amoris laetitia $)^{4}$

Aračić naglašava da se u pastoralnoj djelatnosti Katoličke crkve u Hrvatskoj do sada nije uspio u dovoljnoj mjeri »stvoriti sustav međusobno povezanog ili cjelovitog pastorala braka i obitelji, kao ni kontinuitet, trajnost « (Aračić, 2006, 490). Postoje doduše primjeri dobre prakse, kao što je primjerice »riječki model « (Vranješ, 2010), no to su lokalni modeli bez većega odjeka na nacionalnoj razini. ${ }^{5}$ Ostvarenje obiteljskoga pastorala zahtijeva svestrano i strpljivo zalaganje mjesnih biskupa, stručnih djelatnika i samih kršćanskih obitelji (Šimunović i Čačić, 2008, 481).

Ulaganje dodatnih napora u razvoj i kontinuitet cjelovitoga pastorala braka i obitelji izuzetno je bitno kada se uzme u obzir da upravo obitelj ima važnu, ako ne i presudnu ulogu u predaji vjere. Navedeno potvrđuje istraživanje Vjera i moral u Hrvatskoj (Čovo i Mihalj, 2008), gdje dobiveni rezultati pokazuju da 72,8\% ispitanika smatra kako obitelj utječe na oblikovanje njihova vjerskoga osjećaja

4 Osobito se to odnosi na osmo poglavlje pobudnice Amoris laetitia (Garmaz i Volenik, 2017).

5 Riječ je o dobro usklađenih pet razina pastoralnoga djelovanja: priprava za brak (zaručnički tečajevi), roditeljska škola (praćenje mladih bračnih parova), bračno i obiteljsko savjetovalište, obiteljska škola i zajednice obitelji te bračna i obiteljska duhovnost (Vranješ, 2010, 538-539). Dodatno podsjećamo i na sličan »đakovački model« (Aračić, 2000, 81-87) pastoralnoga djelovanja te dugogodišnji rad hrvatskih isusovaca kroz Obiteljsku ljetnu školu i Zajednicu bračnih susreta, osobito njihov Vikend za zaručnike. 
(Valković, 1998, 485). Navedeno ukazuje na to da je obitelj temeljni pokretač vjerskoga identiteta, što obvezuje na zauzetiji pastoralni rad na tom području. Važnost obitelji vidi se i u istraživanju Franjevačkoga instituta za kulturu mira, gdje u biranju između životnoga uspjeha i obitelji 80,4\% građana rješava tu dvojbu u korist obitelji. Istovremeno, navedeno istraživanje ukazuje na porast sklonosti individualizmu i zapostavljanju kršćanskih vrijednosti, osobito kod mlađih i školovanijih osoba u Hrvatskoj. U spomenutom istraživanju (Čovo i Mihalj, 2008, 55-56), na pitanje što najviše cijene hrvatski građani, od dvadeset mogućih odgovora tek na sedmom mjestu dolazi skladna obitelj $(19,1 \%)$, a na šestom su djeca $(20,7 \%)$.

\section{Zaručnički tečajevi u okviru pastorala braka i obitelji}

Kada se cjelovito sagleda trenutačno stanje po pitanju pastorala braka i obitelji u Hrvatskoj, može se zaključiti da Katolička crkva u Hrvatskoj nema do kraja sustavno razvijen pastoral braka i obitelji koji bi vodio računa o svim navedenim čimbenicima. U mnogim je biskupijama obiteljski pastoral tek formalan i uspu$\tan ^{6}$ te se oslanja na ono što nazivamo predženidbeni pastoral. Taj pastoral ima svoju višegodišnju praksu i povijest, a dijeli se na tzv. dalju, bližu i neposrednu pripravu za brak (Hrvatska biskupska konferencija, 2020, 31-34). Dalja priprava za brak započinje već kroz najranije djetinjstvo i usvajanje temeljnih životnih vrijednosti u krugu obitelji (Šimunović i Čačić, 2008), a nastavlja se i kroz školski vjeronauk, odabranim temama koje obrađuju brak i obitelj. Na dalju pripravu nadovezuje se bliža priprava za brak u formi tzv. zaručničkih tečajeva, koji predstavljaju dragocjenu, ali često nedovoljno iskorištenu prigodu uspostavljanja odnosa između budućih bračnih parova i crkvene zajednice usmjerene na pastoral braka i obitelji. Naime, svi parovi koji namjeravaju sklopiti sakramentalni brak u Katoličkoj crkvi obvezni su proći zaručnički tečaj u kojem se obrađuju različite teme, poput teološko-biblijske vizije braka, pitanja plodnosti i seksualnosti u braku, otvorenosti životu i prirodnoga planiranja obitelji, ${ }^{7}$ bračne komunikacije, različitih bračnih izazova, kao što su rješavanje bračnih sukoba, zajednički odgoj djece, rast u partnerskom odnosu i slično. Današnji oblik zaručničkih tečajeva, iako nije do kraja standardiziran, sličnoga je oblika u svim (nad)biskupijama u Hrvatskoj. Tečajevi traju obično desetak školskih sati, a najčešće su organizirani u večernjim terminima kroz pet dana, obično od ponedjeljka do petka. Najveći su manjak tih tečajeva redovito prevelike grupe i frontalni način rada predavača, pri čemu se ostvaruje obično vrlo malo interakcije koja bi dovela do nekih bitnijih uvida ili pravoga interesa slušača.

6 Postoje brojna savjetovanja i skupovi koji za temu imaju posliježenidbeni pastoral, no vrlo malo od toga biva aplicirano na terenu. »Radi se o načinu rada koji još uvijek u svojoj svijesti ima predodžbu pastorala čiji je nositelj otajstveno a ne i kraljevsko svećeništvo, u 'dijalektičko asimetričnomu reciprocitetu'. U takvoj postavci pastorala, brak i obitelj nisu nositelj (subjekti), kao ujedinjujući čimbenik svega pastorala, nego samo predmet (objekt) crkvenoga rada« (Čondić, 2010, 269).

7 Bilingsova metoda i family care metoda. 


\section{Cilj i problemi istraživanja}

U nastavku ovoga rada fokus je stavljen na prikaz rezultata istraživanja provedenoga s polaznicima zaručničkih tečajeva na području središnje Hrvatske. Riječ je o jednom od rijetkih istraživanja u Hrvatskoj provedenoga na uzorku zaručnika koji žele sklopiti sakramentalni brak u Katoličkoj crkvi. ${ }^{8}$

Cilj je istraživanja ispitati obilježja i produbiti spoznaje o obilježjima partnerskih odnosa zaručnika koji se nalaze u fazi bliže pripreme za sakramentalni brak. Također, želi se provjeriti kako zaručnici procjenjuju važnosti vjere u osobnom životu te kakav je suodnos između njihove religioznosti i promatranih obilježja partnerskoga odnosa. Tim temama važno je posvetiti pažnju u okviru predženidbenoga pastorala, kako bi se zaručnicima pružila mogućnost da dublje sagledaju svoj odnos te da bi ih se potaknulo na unaprjeđivanje kvalitete svojega budućega bračnoga zajedništva.

U skladu s navedenim ciljem definirani su sljedeći problemi istraživanja: 1) ispitati kakva su osnovna obilježja partnerskih odnosa zaručnika (način upoznavanja, životna dob u početku veze, ukupno trajanje veze, trajanje zaruka, iskustvo kohabitacije, predbračne trudnoće i rođenja djeteta); 2) ispitati kako zaručnici procjenjuju važnost vjere u osobnom životu; 3) testirati postoje li razlike u obilježjima partnerskih odnosa ovisno o procjeni važnosti vjere u osobnom životu sudionika istraživanja.

\section{Metodologija istraživanja}

\subsection{Sudionici istraživanja}

Istraživanjem je obuhvaćeno 245 osoba i to: 82 sudionika zaručničkoga tečaja u župi Sv. Petar iz Zagreba; 98 sudionika zaručničkoga tečaja u župi Sv. Mati slobode iz Zagreba; 25 sudionika u župi Sv. Alojzija u Popovači; 40 sudionika u župi Sv. Franje Asiški u Lipiku. U istraživanju je sudjelovalo 122 parova zaručnika te jedna sudionica čiji je partner bio odsutan s tečaja u vrijeme provođenja istraživanja (122 muškarca i 123 žene). Dob sudionika istraživanja kreće se od 20 do 45 godina $(\mathrm{M}=28,51, \mathrm{SD}=4,04)$. Većina sudionika $(\mathrm{N}=129)$ ima završenu višu školu ili fakultet $(\mathrm{N}=129 ; 52,9 \%)$, te srednju školu $(\mathrm{N}=98 ; 40,2 \%)$. Poslijediplomsko obrazovanje ima 14 sudionika (5,7\%), a osnovnoškolsko obrazovanje ima troje sudionika $(1,2 \%)$. Većina je sudionika zaposleno, točnije njih 225 (91,9\%), 10 ih je nezaposlenih (4,1\%), 5 je na školovanju (2\%), a 5 se nije izjasnilo vezano uz radni status $(3 \%)$.

8 Rezultate ovoga istraživanja moguće je usporediti s rezultatima istraživanja koje su na istoj populaciji zaručnika proveli Šimunović i Čačić (2008) anketom među zaručnicima koji su pohađali zaručnički tečaj u okviru zagrebačke župe Sv. Križ. Nešto je starija i metodološki različita studija polaznika zaručničkih tečajeva u više hrvatskih biskupija kako donosi Aračić (2000). 


\subsection{Postupak istraživanja}

Podatci su prikupljeni anketiranjem zaručnika na zaručničkim tečajevima u različitim župama Zagrebačke nadbiskupije. U gradu Zagrebu istraživanje je provedeno u župama Sv. Petar, koja pokriva uži centar grada, i u župi Sv. Mati slobode na zagrebačkom Jarunu, koja pokriva šire gradsko područje. Istraživanje je provedeno i izvan Zagreba u manjim sredinama na području Sisačke i Požeške biskupije. Anketiranje je provedeno u dogovoru s animatorima tečaja, obično u vrijeme predavanja psihologa ili na samom kraju tečaja. Istraživanje je provedeno anonimno na način da su svi zainteresirani polaznici dobili mogućnost da svatko za sebe popuni po jedan anketni list, pri čemu su zaručnici dobili anketne listiće u paru (označene istim rednim broj, ali različitim predznakom), kako bi se prilikom unosa i obrade prikupljenih podataka njihovi odgovori mogli upariti. Prije popunjavanja upitnika zaručnicima je objašnjena svrha i cilj istraživanja, te su zamoljeni za sudjelovanje u istraživanju. Sudjelovanje u istraživanju bilo je dobrovoljno. Sudionicima istraživanja osigurana je povjerljivost podataka. S obzirom na to da na tečajevima parovi redovito sjede zajedno, prije početka istraživanja sudionici su zamoljeni da se razdvoje za vrijeme popunjavanja upitnika (samostalno popunjavanje svakoga člana para kao temeljni preduvjeti da svaki sudionik može iskreno odgovoriti na sva pitanja, bez zajedničkoga konzultiranja oko određenih "osjetljivijih tema”). Prosječno vrijeme popunjavanja upitnika bilo je 50 minuta.

Upitnikom su prikupljeni podatci o sociodemografskim obilježjima sudionika istraživanja (dob, spol, stupanj obrazovanja, radni status, procjena materijalnoga statusa te procjena važnosti vjere u osobnom životu) i podatci o obilježjima njihove partnerske veze (način upoznavanja, s koliko su se godina upoznali, trajanje partnerskoga odnosa, trajanje zaruka, iskustvo kohabitacije, trudnoće, zajednička djeca ili djeca iz prethodnih veza). Unos i obrada podataka provedena je pomoću programskoga paketa SPSS 10.

\section{Rezultati i rasprava}

U prvom dijelu rezultata istraživanja prikazani su deskriptivni podatci o osnovnim obilježjima partnerskih odnosa polaznika zaručničkih tečajeva.

Tablica 1. Obilježja partnerskoga odnosa — zastupljenost po kategorijama Table 1. Characteristics of the partners' relationship — representation by categories

\begin{tabular}{|l|l|c|c|}
\hline & Odgovor & $N$ & Postotak \\
\hline \multirow{2}{*}{$\begin{array}{l}\text { Način upoznavanja } \\
\text { zaručnika }\end{array}$} & Uživo & 216 & $88,9 \%$ \\
\cline { 2 - 4 } & Kroz online komunikaciju & 27 & $11,1 \%$ \\
\hline \multirow{2}{*}{$\begin{array}{l}\text { Život u zajedničkom } \\
\text { kućanstvu prije braka }\end{array}$} & $\mathrm{Ne}$ & 71 & $29 \%$ \\
\cline { 2 - 4 } & $\mathrm{Da}$ & 174 & $71 \%$ \\
\hline
\end{tabular}




\begin{tabular}{|c|c|c|c|}
\hline \multirow[t]{2}{*}{ Trenutačna trudnoća } & $\mathrm{Ne}$ & 217 & $88,6 \%$ \\
\hline & $\mathrm{Da}$ & 27 & $11 \%$ \\
\hline \multirow{2}{*}{$\begin{array}{l}\text { Zajednička djeca prije } \\
\text { braka }\end{array}$} & $\mathrm{Ne}$ & 222 & $91,7 \%$ \\
\hline & $\mathrm{Da}$ & 20 & $8,3 \%$ \\
\hline \multirow[t]{2}{*}{ Djeca iz ranije veze } & $\mathrm{Ne}$ & 240 & $98,4 \%$ \\
\hline & $\mathrm{Da}$ & 4 & $1,6 \%$ \\
\hline \multirow{5}{*}{$\begin{array}{l}\text { Procjena u kojoj mjeri } \\
\text { postojeći prihodi i } \\
\text { ekonomska situacija } \\
\text { zadovoljavaju potrebe } \\
\text { buduće obitelji }\end{array}$} & Uopće ne & 2 & $0,8 \%$ \\
\hline & Malo & 20 & $8,2 \%$ \\
\hline & Osrednje & 57 & $23,4 \%$ \\
\hline & Puno & 81 & $33,2 \%$ \\
\hline & U cijelosti & 84 & $34,4 \%$ \\
\hline
\end{tabular}

Tablica 2. Prosječne vrijednosti za promatrana obilježja partnerske veze Table 2. Average values for the observed characteristics of the partners' relationship

\begin{tabular}{|l|c|c|c|c|c|}
\hline Obilježja partnerske veze & $N$ & Min & Max & $M$ & $S D$ \\
\hline Ukupno trajanje veze u mjesecima & 245 & 3 & 138 & 64,28 & 36,16 \\
\hline Životna dob (god.) u vrijeme početka veze & 244 & 14 & 42 & 23,18 & 5,00 \\
\hline $\begin{array}{l}\text { Prije koliko mjeseci je donesena odluka o } \\
\text { vjenčanju }\end{array}$ & 240 & 1 & 48 & 11,67 & 9,12 \\
\hline
\end{tabular}

Dobiveni rezultati pokazuju da je većina sudionika istraživanja svoje partnere upoznala u izravnom kontaktu $(88,9 \%, \mathrm{~N}=216)$, a njih je $11,1 \%(\mathrm{~N}=27)$ partnera upoznalo preko online komunikacije. Raspon vremena od kad je donesena odluka o vjenčanju kreće se od 1 do 48 mjeseci $(M=11,67, S D=9,124)$, a ukupno je trajanje veze od 3 mjeseca do 11,5 godina.

Što se tiče procjene materijalne situacije, $67,4 \%$ sudionika procjenjuje da njihova sadašnja primanja mogu podmiriti očekivane financijske potrebe njihove buduće obitelji. Istovremeno jedna četvrtina sudionika smatra da neće imati dovoljno financijskih sredstava za budući zajednički život.

Ono što se posebno ističe među dobivenim rezultatima pokazatelji su da gotovo dvije trećine zaručnika koji žele sklopiti crkveni brak $(71,0 \%)$ živi nevjenčano u zajedničkom kućanstvu, a još kod četvrtine njih $(20,8 \%)$ trenutačno je prisutna trudnoća $(11,0 \%)$ ili već postoje rođena zajednička djeca $(8,2 \%)$. Istovremeno, zanemarivo je mali postotak parova u kojima netko od zaručnika ima djecu iz prethodnih veza (1,6\%). Treba primijetiti da dobiveni podatak o visokom postotku od $71 \%$ zaručnika koji kohabitiraju prije braka bitno odudara od podatka iz posljednjeg popisa stanovništva Hrvatske, prema kojem samo 2,69\% stanovnika iznad petnaeste godine života živi u izvanbračnoj zajednici (Državni zavod za sta- 
tistiku, s. a.a). ${ }^{9}$ Navedenu diskrepanciju treba sagledati u kontekstu specifičnoga selekcioniranoga uzorka zaručnika koji je obuhvaćen ovim istraživanjem u odnosu na populaciju stanovnika Hrvatske starijih od 15 godina, u koju ulaze različite, pa i starije generacije stanovništva, kod kojih su stope kohabitacije zasigurno puno niže. Nadalje, moguće je da je riječ o kratkotrajnim periodima pojačanih stopa kohabitacije zaručnika neposredno pred ulazak u brak. Ne treba isključiti ni mogućnost većega povećanja stopa kohabitacije u općoj populaciji Hrvatskoj u razdoblju od posljednjega popisa stanovništva do danas, što je važno provjeriti u budućim istraživanjima i nadolazećem popisu stanovništva.

U sljedećem koraku istraživanja ispitane su procjene sudionika istraživanja o važnosti vjere u njihovu osobnom životu.

Tablica 3. Procjena važnosti vjere u osobnom životu

Table 3. Assessment of the importance of faith in one's personal life

\begin{tabular}{|l|c|c|}
\hline Važnosti vjere u osobnom životu & $N$ & Postotak \\
\hline Izrazito nevažno & 5 & $2,1 \%$ \\
\hline Nevažno & 11 & $4,5 \%$ \\
\hline Osrednje & 58 & 23,9 \\
\hline Važno & 109 & 44,9 \\
\hline Izrazito važno & 60 & 24,7 \\
\hline
\end{tabular}

Dobiveni podatci u ovom dijelu istraživanja pokazali su da čak $71,0 \%$ sudionika istraživanja smatra vjeru važnom ili izrazito važnom u svojem životu, 23,9\% osrednje važnom, a tek 6,5\% nevažnim ili izrazito nevažnim. Rezultati ranijega istraživanja Šimunović i Čačić (2008) provedenog na uzorku od 186 polaznika zaručničkih tečajeva u Župi Sv. Križa u Zagrebu, u kojem se religiozna dimenzija kod zaručnika mjerila kroz kategorije tradicionalni vjernik, uvjereni vjernik i formalni vjernik (vjeruje, ali ne prakticira), pokazali su da $42 \%$ zaručnika i $35 \%$ zaručnica sebe svrstava u kategoriju tradicionalnih vjernika, a 30\% zaručnika i $45 \%$ zaručnica sebe opisuje kao uvjerene vjernike koji razmišljaju i žive kršćansku vjeru potaknuti obiteljskim i crkvenim svjedočanstvima te osobnim iskustvima i duhovnim potrebama. Istovremeno, $28 \%$ zaručnika i $20 \%$ zaručnica izjašnjava se da su formalni vjernici koji se ne opterećuju pitanjima vezanim uz vjerski život te da najčešće ne prakticiraju javno vjeru (Šimunović i Čačić, 2008, 475). Neovisno o tom što je u navedenim istraživanjima bila riječ o različitim mjerama religioznosti, podatci pokazuju da najveći postotak polaznika zaručničkih tečajeva sebe opisuje kao uvjerene vjernike te smatra da im je vjera važna u osobnom životu, no istovremeno nije zanemariv ni broj onih kojima pitanja vezana uz vjeru nisu važna u osobnom životu.

9 Prema Popisu stanovništva iz 2011. godine, od ukupno 1,731.610 muškaraca i 1,900.851 žena starosne dobi iznad 15 godina (3,632.461 stanovnika) u izvanbračnoj zajednici živi ukupno 48.886 muškaraca i 48.886 žena (2,69\%), a istovremeno je u braku 959.487 muškaraca i 959.487 žena $(52,83 \%)$. 
Tablica 4. Prosječne vrijednosti i razlike prema spolu u procjenama važnosti vjere u osobnom životu

Table 4. Average values and male-female differences in the assessment of the importance of faith in one's personal life

\begin{tabular}{|c|c|c|c|c|c|c|c|c|c|}
\hline $\begin{array}{l}\text { Važnost vjere } \\
\text { u osobnom } \\
\text { životu }\end{array}$ & $N$ & Min & $\operatorname{Max}$ & $M$ & $S D$ & $t$ & $d f$ & $p$ & $\begin{array}{l}\text { Cohenov d } \\
\text { indeks }\end{array}$ \\
\hline Muško & 121 & 1 & 5 & 3,70 & 0,963 & \multirow[t]{3}{*}{$-2,640$} & \multirow[t]{3}{*}{241} & \multirow[t]{3}{*}{0.009} & \multirow[t]{3}{*}{$-0,33$} \\
\hline Žensko & 122 & 2 & 5 & 4,01 & 0,838 & & & & \\
\hline Ukupno & 243 & 1 & 5 & 3,86 & 0,914 & & & & \\
\hline
\end{tabular}

Izračunavanje statističke značajnosti razlike putem t-testa pokazalo je da postoji značajna razlika u doživljaju važnosti vjere u osobnom životu prema spolu $(\mathrm{p}=0,009)$, pri čemu je utvrđeno da žene u odnosu na muškarce važnost vjere $u$ osobnom životu procjenjuju bitno višim ocjenama. Istovremeno, navedene razlike nisu nađene prema stupnju obrazovanja sudionika istraživanja $(F=0,64$; $d f$ $=3 ; \mathrm{p}=0,979)$.

U narednom koraku testirane su razlike u obilježjima partnerskih odnosa ovisno o procjeni važnosti vjere u osobnom životu sudionika istraživanja.

Tablica 5. Razlike u zastupljenosti iskustva kohabitacije, predbračne trudnoće i izvanbračnog rođenja djeteta ovisno o procjeni važnosti vjere u osobnom životu Table 5. Differences in the prevalence of cohabitation experience, premarital pregnancy and out-of-wedlock childbirth depending on an assessment of the importance of faith in one's personal life

\begin{tabular}{|c|c|c|c|c|c|c|c|c|c|}
\hline \begin{tabular}{|l|} 
Procjena \\
važnosti vjere
\end{tabular} & $N$ & Min & $\operatorname{Max}$ & $M$ & $S D$ & $t$ & $d f$ & $p$ & \begin{tabular}{|l} 
Cohenov \\
dindeks
\end{tabular} \\
\hline \begin{tabular}{|l|} 
Ne žive u \\
zajedničkom \\
kućanstvu
\end{tabular} & 70 & 2 & 5 & 4,14 & 0,785 & \multirow[t]{3}{*}{3,136} & \multirow[t]{3}{*}{239} & \multirow[t]{3}{*}{0,002} & \multirow[t]{3}{*}{0,44} \\
\hline $\begin{array}{l}\text { Žive u } \\
\text { zajedničkom } \\
\text { kućanstvu } \\
\end{array}$ & 173 & 1 & 5 & 3,73 & 0,938 & & & & \\
\hline \begin{tabular}{|l|} 
Ukupno \\
\end{tabular} & 243 & 1 & 5 & 3,86 & 0,914 & & & & \\
\hline $\begin{array}{l}\text { Zaručnici bez } \\
\text { trudnoće }\end{array}$ & 216 & 1 & 5 & 3,83 & 0,922 & \multirow{3}{*}{$-1,515$} & \multirow{3}{*}{240} & \multirow{3}{*}{0,131} & \multirow{3}{*}{$-0,31$} \\
\hline $\begin{array}{l}\begin{array}{l}\text { Zaručnici s } \\
\text { trudnoćom }\end{array} \\
\end{array}$ & 26 & 2 & 5 & 4,12 & 0,816 & & & & \\
\hline Ukupno & 242 & 2 & 5 & 3,86 & 0,914 & & & & \\
\hline \begin{tabular}{|l} 
Nemaju \\
zajedničke \\
djece
\end{tabular} & 221 & 1 & 5 & 3,89 & 0,900 & \multirow[t]{3}{*}{$-0,261$} & \multirow[t]{3}{*}{239} & \multirow[t]{3}{*}{0,795} & \multirow[t]{3}{*}{$-0,15$} \\
\hline $\begin{array}{l}\text { Imaju } \\
\text { zajedničke } \\
\text { djece }\end{array}$ & 19 & 1 & 5 & 3,47 & 1,020 & & & & \\
\hline Ukupno & 240 & 1 & 5 & 3,85 & 0,915 & & & & \\
\hline
\end{tabular}


Testiranje razlika putem t-testa pokazalo je da između promatranih skupina zaručnika koji imaju iskustvo zajedničkoga predbračnoga života i onih koji ne žive zajedno u kohabitaciji postoji statistički značajna razlika u pogledu procjene važnosti vjere $\mathrm{u}$ osobnom životu i to na razini $\mathrm{p}<0,01(\mathrm{p}=0,002)$. Pri tom je očekivano potvrđeno da osobe koje ne žive u zajedničkom kućanstvu sa zaručnikom u bitno većoj mjeri procjenjuju važnost vjere u osobnom životu.

S druge strane, kod varijable predbračne trudnoće $(\mathrm{p}=0,131)$, kao i kod rođenja zajedničke djece prije sklapanja braka $(\mathrm{p}=0,795)$, nije utvrđeno postojanje statističke značajnosti razlike ovisno o procjeni važnosti vjere u životu sudionika istraživanja. Tu treba napomenuti da je moguće da navedene razlike nisu potvrđene zbog niske zastupljenosti poduzorka zaručnika koji su postali roditelji ili se nalaze u periodu iščekivanja rođenja djeteta, pa je te rezultate u budućim istraživanjima na širem uzorku preporučljivo dodatno provjeriti.

\section{Zaključak}

U zadnjih nekoliko desetljeća nevjenčani zajednički život partnera postaje sve češće prethodnik i alternativni oblik braka u zapadnim zemljama, ali i u $\mathrm{Hr}$ vatskoj. Dobiveni rezultati u ovom istraživanju potvrdili su da i među parovima koji žele sklopiti crkveni, sakramentalni brak velika većina parova ima iskustvo predbračnoga zajedničkoga života, a dio njih ostvario se već i u roditeljskoj ulozi ili se nalazi u iščekivanju rođenja djeteta.

Uočena visoka razina prisutnosti kohabitacije ukazuje na važnu činjenicu koja se ne smije zanemariti u okviru predženidbenoga pastorala, a to je da uvjerljiva većina parova koja dolazi na zaručničke tečajeve već živi svoj partnerski odnos daleko od tradicionalne slike zaručništva, koja je nespojiva s kohabitacijom ili predbračnim rođenjem djeteta. Navedeno ukazuje na potrebu da se takvim parovima u okviru zaručničkih tečajeva obraća s pozicije prepoznavanja stvarnosti koju žive. Ujedno to potiče i potrebu za daljnjom raspravom o stvarnoj slici hrvatskoga društva i vjernika u njemu.

$\mathrm{U}$ tom kontekstu dobro je zaključiti s papom Franjom kako on to donosi u svojoj postsinodalnoj pobudnici Amoris laetitia: »Dugo smo mislili da smo jednostavnim isticanjem doktrinarnih, bioetičkih i moralnih pitanja, bez poticanja na otvaranje milosti, već pružili dovoljnu potporu obiteljima, učvrstili bračnu vezu i ispunili smislom njihov zajednički život. Nailazimo na teškoće u predstavljanju braka više kao dinamičkoga puta osobnoga razvoja i ispunjenja, no kao teret koji treba podnositi cijeli život. Mučimo se također dati prostor savjesti vjernika, koji usred svojih ograničenosti vrlo često odgovaraju što je bolje moguće na evanđelje, te su sposobni ostvariti svoje vlastito razlučivanje u složenim situacijama. Pozvani smo odgajati savjesti, a ne težiti tome da ih zamijenimo.» AL 37). 


\section{Literatura}

AL. Amoris laetitia. Franjo, Amoris laetitia: Radost ljubavi: Posinodalna apostolska pobudnica biskupima, prezbiterima i đakonima, posvećenim osobama, kršćanskim supruzima i svim vjernicima laicima o ljubavi u obitelji. Zagreb: Kršćanska sadašnjost.

Alinčić, Mira; Bakarić-Abramović, Ana; Hrabar, Dubravka; Sakovac-Lozić, Dijana; Korač, Aleksandra (2001). Obiteljsko pravo. Zagreb: Narodne novine.

Aračić, Pero (2000). Rasti u ljubavi: Priprava za brak i obitelj i pastoral zaručnika. Zagreb: Glas Koncila.

Aračić, Pero (2006). Odgovornost Crkve za pastoral obitelji. Riječi teološki časopis, 61(4), 479-493.

Axinn, William G.;Thornton, Arland (1992). The relationship between cohabitation and divorce: Selectivity or causal influence? Demography, 29, 357-374.

Baloban, Josip; Črpić, Gordan; Ježovita, Josip (2019). Vrednote u Hrvatskoj od 1999. do 2018. prema European Values Study. Zagreb: Kršćanska sadašnjost.

Blažeka Kokorić, Slavica (2005). Povezanost iskustava u primarnoj obitelji s obilježjima partnerskih odnosa (doktorska disertacija). Zagreb: Pravni fakultet Sveučilišta u Zagrebu.

CCE. Catechismus Catholicae Ecclesiae. Ivan Pavao II., Katekizam Katoličke crkve: Dorađeno izdanje. Zagreb: Hrvatska biskupska konferencija, 2016.

Čalić, Petar (1995). Brak u procjepu: Oženjen, rastavljen, ponovno vjenčan. Zagreb: Glas Koncila.

Čondić, Alojzije (2010). Jesu li brak i obitelj zastarjele ustanove u hrvatskom društvu? Služba Božja, 3(50), 249-272.

Čovo, Ante; Dijana, Mihalj (ur.) (2008). Muško i žensko stvori ih: Žena i muškarac u življenju i u službi Božjeg poslanja. Split: Franjevački institut za kulturu mira.

Čudina-Obradović, Mira; Obradović, Josip (2006). Psihologija braka i obitelji. Zagreb: Golden marketing.

Državni zavod za statistiku (2019). Prirodno kretanje stanovništva u 2018. U: Državni zavod za statistiku. URL: https://www.dzs.hr/Hrv_Eng/publication/2019/SI-1641.pdf (06.12.2020.)

Državni zavod za statistiku (s. a.a). Stanovništvo staro 15 i više godina prema vrsti zajednice u kojoj osoba živi, starosti i spolu, popis 2011. U: Državni zavod za statistiku. URL: https://www.dzs.hr/Hrv/censuses/census2011/results/htm/H01_01_26/H01_01_26. html (06.12.2020.)

Državni zavod za statistiku (s. a.b). Stanovništvo prema vjeri, popisi 2001. i 2011. U: Središnji državni portal. URL: https://data.gov.hr/dataset/popis-stanovni-tva-2001-i-2011stanovni-tvo-prema-vjeri/resource/4ac6a995-3b39-47c5-8a53-d3086340f071 (06.12.2020.)

Garmaz, Jadranka; Volenik, Antun (2017). Pastoralni i odgojno-katehetski naglasci sedmog i osmog poglavlja posinodalne pobudnice Amoris laetitia. Obnovljeni Život, 72(1), 93-108.

Haralambos, Michael; Holborn, Martin (2002). Sociologija: Teme i perspektive. Zagreb: Golden marketing.

Hlača, Nenad (2006). Forma sklapanja braka u Republici Hrvatskoj od "liberalizma" do "katolicizma" i natrag. Bogoslovska smotra, 76(4), 1059-1071.

Hrvatska biskupska konferencija (2002). Direktorij za obiteljski pastoral Crkve u Hrvatskoj. Zagreb: Kršćanska sadašnjost. 
Ilišin, Vlasta (2002). Mladost, odraslost i budućnost. U: Vlasta Ilišin i Furio Radin (ur.), Mladi uoči tré́eg milenija (str. 27-47). Zagreb: Institut za društvena istraživanja.

Koračević, Karlo (1999). Novije promjene u življenju i shvaćanju braka i obitelji. Bogoslovska smotra, 69(2-3), 271-283.

Kregar, Josip; Sekulić, Duško; Ravlić, Slaven; Zrinščak, Siniša; Grubišić, Ksenija; Petričušić, Antonija (2014). Uvod u sociologiju. Zagreb: Pravni fakultet u Zagrebu.

Ministarstvo uprave (2020). Javna uprava vama na usluzi: Statistički prikaz Ministarstva uprave Broj 17. U: Ministarstvo uprave. URL: https://uprava.gov.hr/UserDocsImages//Statisti\%C4\%8Dki\%20prikaz/2020//Statisti\%C4\%8Dki\%20prikaz\%20Ministarstva\%20uprave\%20broj\%2017fin.pdf (03.05.2020.)

Mrđen, Snježana (1997). Rođenja izvan braka u Hrvatskoj. Geoadria, 2, 63-76.

Stafford, Laura; Kline, Susan L.; Rankin, Caroline T. (2004). Married individuals, cohabiters, and cohabiters who marry: A longitudinal study of relational and individual well-being. Journal of Social and Personal Relationships, 21(2), 231-248.

Strong, Brayan; DeVault, Christine; Cohen, Theodore F. (2011). The Marriage and Family Experience: Intimate Relationships in a Changing Society. Belmont: Wadsworth Cengage Learning.

Šimunović, Josip; Čačić, Kristina (2008). Priježenidbeni pastoral — bliža priprema u mjesnoj crkvi. Obnovljeni Život, 63(4), 457-482.

Ustavni sud Republike Hrvatske (2014). Odluka u povodu okončanja postupka nadzora nad ustavnošću i zakonitošću provođenja državnog referenduma održanog 1. prosinca 2013., na kojem je članak 62. Ustava Republike Hrvatske dopunjen novim stavkom 2. Narodne novine, br. 5.

Valković, Marijan (1998). Socioreligijsko istraživanje: Vjera i moral u Hrvatskoj: Djelomično izvješce. Bogoslovska smotra, 68(4), 461-473.

Vranješ, Nikola (2010). Pastoral braka i obitelji po "riječkom modelu": Primjer programatskog djelovanja u obiteljskom pastoralu. Obnovljeni Život, 65(4), 535-547. 
An Analysis of Different Aspects of Partnership among Couples Preparing for Marriage

Antun Volenik*, Slavica Blažeka Kokorić**, Maja Laklija***

Summary

The paper presents the results of a survey conducted on a sample of 244 persons (122 couples) attending a Marriage Preparation Course as an integral part of the immediate preparation for the celebration of the Sacrament of Marriage within the Catholic Church. The aim of the research was to examine the characteristics of engaged couples who are in the phase of immediate preparation for marriage which includes the sacramental dimension. Also, the research tested for differences in the characteristics of such couples depending on an assessment of the importance of faith in their personal life. The results showed that $71 \%$ of the participants lived a joint life with their fiancéffiancée before marriage, $11 \%$ of them entered marriage already expecting a child, and another $8.3 \%$ with their child already born. Cohabitation is significantly less frequent in the case of engaged couples who exhibited the importance of faith in their personal life to a higher degree.

The data obtained in this part of the research showed that as many as $71.0 \%$ of research participants consider religion to be important or extremely important in their lives and only $6.5 \%$ consider it unimportant or extremely unimportant.

The results obtained through ANOVA showed that — between the groups of fiancés who lived together before marriage and those who did not — there is a statistically significant difference which is contingent upon the importance of faith in one's personal life, especially in terms of the differences in attitude between men and women. Based on the data obtained, the article addresses the current state of marriage and family pastoral care in the Republic of Croatia and proposes some adjustments with regard to the premarital life of the majority of couples.

Key words: marriage; the Sacrament of Marriage; preparation for marriage; partnerships

* Antun Volenik, Ph.D., Assistant Professor, Faculty of Philosophy and Religious Studies, University of Zagreb, Address: Jordanovac 110, 10000 Zagreb, Croatia. E-mail: voleniksj@gmail.com

** Slavica Blažeka Kokorić, Ph.D., Full Professor, Social Work Study Centre, Faculty of Law, University of Zagreb, Address: Nazorova 51, 10000 Zagreb, Croatia. E-mail: sblazeka@pravo.hr

*** Maja Laklija, Ph.D., Associate Professor, Social Work Study Centre, Faculty of Law, University of Zagreb, Address: Nazorova 51, 10000 Zagreb, Croatia. E-mail: maja.laklija@pravo.hr 